\title{
Instrumentation and control of large helium cryogenic systems
}

\author{
J. G. Weisend II
}

\section{${ }^{*}$ Correspondence:}

JohnG.Weisendll@ess.eu Lund University, European Spallation Source ERIC, P.O Box 176, SE-221 00 Lund, Sweden
(C) The Author(s). licensee Springer on behalf of EPJ, 2021, corrected publication 2021. Open Access This article is licensed under a Creative Commons Attribution 4.0 International License, which permits use, sharing, adaptation, distribution and reproduction in any medium or format, as long as you give appropriate credit to the original author(s) and the source, provide a link to the Creative Commons licence, and indicate if changes were made. The images or other third party material in this article are included in the article's Creative Commons licence, unless indicated otherwise in a credit line to the material. If material is not included in the article's Creative Commons licence and your intended use is not permitted by statutory regulation or exceeds the permitted use, you will need to obtain permission directly from the copyright holder. To view a copy of this licence, visit http://creativecommons.org/licenses/by/4.0/. The Creative Commons Public Domain Dedication waiver (http://creativecommons.org/publicdomain/zero/1.0/) applies to the data made available in this article, unless otherwise stated in a credit line to the data. 


\section{Acknowledgements}

None provided.

Authors' contributions

The section EiC is the sole author. The author(s) read and approved the final manuscript.

Funding

None.

Availability of data and materials

There are neither data nor other materials associated with this article.

\section{Declarations}

Competing interests

The author declares that the author has no competing interests.

Published online: 17 August 2021

\section{Publisher's Note}

Springer Nature remains neutral with regard to jurisdictional claims in published maps and institutional affiliations.

Submit your manuscript to a SpringerOpen ${ }^{\circ}$ journal and benefit from:

- Convenient online submission

- Rigorous peer review

- Open access: articles freely available online

- High visibility within the field

- Retaining the copyright to your article

Submit your next manuscript at $\gg$ springeropen.com 